\title{
Pelatihan Keterampilan Dasar-dasar Cabang Olahraga Renang pada Sekolah Renang Akuatik Jakarta Timur
}

\author{
Asrori Yudha Prawira ${ }^{1^{*}}$, Faridatul A'la ${ }^{2}$ \\ 1,2Pendidikan Kepelatihan Olahraga, Fakultas IImu Pendidikan, Universitas \\ Bhayangkara Jakarta Raya, Jl. Harsono RM No.67, RT.7/RW.4, Ragunan, Pasar \\ Minggu, Jakarta Selatan, Jakarta 12550. Telp : (021) 88955882, 88955871, \\ asrori.yudhaprawira@dsn.ubharajaya.ac.id, faridatul@dsn.ubharajaya.ac.id
}

*Korespondensi : asrori.yudhaprawira@dsn.ubharajaya.ac.id

Diterima: 30 September 2021 ; Review: 11 Desember 2021 ; Disetujui: 26 Desember 2021 ; Diterbitkan: 31 Desember 2021

\begin{abstract}
The purpose of this community service is to create a forum so that the actualization of children can run well, where children can carry out positive activities that are useful outside of formal education, especially in the field of Swimming Branch Sports. It is hoped that the children can also interact socially with each other and have positive and directed recreation in an integrated environment between educational and recreational activities that are comfortable and form a sporty and competitive spirit. Promote sports and cultivate the community. Implementation Time Friday and Saturday from 15.00 to 17.00, Location for the Implementation of the Permata Timur II Swimming Pool Facility, East Jakarta. Starting from the identification of existing problems from the target analysis which is then formulated as a problem to be overcome through this community service activity, steps and theoretical concepts are needed as an alternative approach to solving the problem. Through training methods, namely direct practice with an explanation of the material, with an explanation of the theory of the target to know and understand the concept of the sport of swimming. Then by doing direct practice.
\end{abstract}

Keywords : Community, sport, swimming

\begin{abstract}
Abstrak
Tujuan dari pengabdian masyarakat ini adalah agar tercipta suatu wadah agar aktualisasi anak-anak bisa berjalan dengan baik, dimana anak-anak dapat melakukan kegiatan positif yang bermanfaat diluar pendidikan formal kususnya dibidang Olahraga Cabang Renang. Diharapkan para anak-anak juga dapat berinteraksi sosial dengan sesamanya dan berekreasi secara positif serta terarah dalam lingkungan terpadu antara kegiatan edukatif dan rekreatif yang nyaman serta membentuk jiwa sportif dan kompetitif. Memasyarakatkan olahraga dan mengolahragakan masyarakat. Waktu Pelaksanaan Jumat dan Sabtu pukul 15.00 s.d 17.00, Lokasi Pelaksanaan Fasilitas Kolam Renang Permata Timur II Jakarta Timur. Bertitik tolak dari identifikasi masalah yang ada dari analisis sasaran yang kemudian dirumuskan sebagai masalah yang akan diatasi melalui kegiatan pengabdian masyarakat ini, maka diperlukan langkah-langkah dan konsep-konsep teori sebagai pendekatan alternatif untuk memecahkan masalah. Melalui metode pelatihan, yaitu praktek langsung dengan penjelasan materi, dengan penjelasan teori sasaran mengetahui dan memahami konsep tentang cabang olahraga renang. Kemudian dengan melakukan praktek langsung.
\end{abstract}

Kata Kunci : Masyarakat, olahraga, renang 


\section{PENDAHULUAN}

Menurut (Menkumham RI Patent No. 3 Undang-Undang Republik Indonesia tentang: Sistem Keolahragaan Nasional, 2005) Tentang Sistem Keolahragaan Nasional yaitu "Pembina olahraga adalah orang yang memiliki minat dan pengetahuan, kepemimpinan, kemampuan manajerial, dan/atau pendanaan yang didedikasikan untuk kepentingan pembinaan dan pengembangan olahraga."

Pembinaan olahraga saat ini dikenal menjadi dua sistem yang umumnya dianut di negara-negara maju, yaitu pembinaan olahraga dengan menonjolkan pada olahraga elit (elite sport) dan pembinaan olahraga yang memfokuskan pada budaya gerak (sport and movement culture) yang berujung pada perilaku hidup sehat. (Mutohir, 2004) Pembinaan olahraga yang berfokus pada budaya gerak sangatlah penting bagi anak-anak dalam rangka menyalurkan minat dan bakat dibidang Olahraga khususnya cabang olahraga renang, sehingga para anak-anak dapat memanfaatkan waktu luar sekolah dengan kegiatan yang positif dan wadah olahraga untuk meningkatkan kemampuan dan kebugaran. Tujuan akhir pembinaan olahraga itu tidak lain untuk meningkatkan kualitas hidup masyarakat, sehingga secara konsisten perlu menempatkan olahraga sebagai bagian integral dari pembangunan (Ditjora Depdiknas, 2003).

Cabang olahraga yang dapat digunakan untuk mencapai tujuan tersebut, diantaranya adalah cabang olahraga renang. Renang merupakan salah satu cabang olahraga yang dapat diajarkan pada anak-anak dan orang dewasa, bahkan bayi yang berumur beberapa bulan saja sudah dapat mulai diajarkan renang (Kasiyono, 1979). Alasan mengapa cabang renang dapat digunakan untuk mencapai tujuan pendidikan jasmani adalah karena renang memiliki banyak manfaat. Manfaat tersebut diantaranya dapat membantu pertumbuhan dan perkembangan tubuh, bersosialisasi dan berinteraksi dengan orang lain, menambah kepercayaan pada diri sendiri, dan dapat digunakan sebagai kegiatan rekreatif karena rangsangan dingin dapat menyegarkan tubuh dan perasaan. Belajar renang juga dapat menambah pengetahuan siswa tentang gerak yang efektif dan efisien, sifat-sifat air, teori renang dan lain-lain.

Selain itu juga Pembinaan Olahraga Renang diharapkan dapat menciptakan anakanak, masyarakat khusunya generasi - generasi muda mempolakan keterampilan dan kebugaran jasmani para anak-anak secara multilateral (menyeluruh) dan spesialisasi (atlet binaan yang memiliki keistimewaan dalam olahraga tertentu), yang bertujuan untuk melibatkan atlet sebanyak-banyaknya dalam olahraga prestasi, sehingga timbul minat dan motivasi dalam menunjukkan kemampuan terbaiknya dalam upayanya meningkatkan prestasi olahraga, serta mengolahragakan masyarakat dengan anak-anak yang sehat dan bugar. (Badan Standard Nasional Pendidikan, 2006) menyatakan bahwa Pembinaan Olahraga merupakan bagian integral dari pendidikan secara keseluruhan, bertujuan untuk mengembangkan aspek kebugaran jasmani, keterampilan gerak keterampilan berfikir kritis, keterampilan social, penalaran, stabilitas emosional, tindakkan moral, aspek pola hidup sehat dan pengenalan lingkungan bersih melalui aktivitas jasmani, olahraga dan kesehatan terpilih yang direncanakan secara sistematis dalam rangka mencapai tujuan pendidikan nasional.

Pembinaan olahraga cabang renang ini suatu wadah olahraga dimana kegiatan luar sekolah untuk meningkatkan kebugaran jasmani serta menjaring potensi anak-anak yang berkeinginan menguasai dan mencintai olahraga renang. Adapun kompetisi olahraga antar pelajar sudah mulai digalakan oleh Dinas dan Suku Dinas Olahraga DKI Jakarta dimana ada kegiatan pemasalan kejuaraan antar pelajar SD, SMP, SMA, Sampai Perguruan Tinggi Se DKI Jakarta.

Pada prinsipnya proses pembelajaran renang prinsipnya tidak berbeda dengan mengajar materi yang lain, seperti atletik, senam, dan permainan. Proses pembelajaran pendidikan jasmani baik guru maupun pelatih juga harus mempertimbangkan keseluruhan aspek kepribadian anak. Untuk membimbing anak-anak menuju menjadi aktif secara fisik untuk seumur hidup, aktivitas fisik (pendidikan jasmani) melalui pengalaman pendidikan pada anak usia dini harus meliputi (a) belajar dari perkembangan keterampilan yang sesuai, (b) personil terlatih dalam praktik pembelajaran yang tepat untuk kegiatan fisik, 
(c) promosilingkungan aktivitas fisik yang positif dan aman, termasuk peralatan ukuran anak-anak, dan (d) kurikulum inklusif didasarkan pada pemahaman konsep gerakan dan tema keterampilan (Stork \& Sanders, 2008). Dalam prosesnya, pengajar harus lebih disiplin dengan keselamatan siswa, karena akan berakibat fatal jika terjadi kecelakaaan. Tak jarang pula ada yang cedera hingga memakan korban jiwa. Olehnya itu sangat penting, guru mengetahui dengan baik teori maupun praktik terkait dengan metode pembelajarn renang.

Fakta dilapangan menunjukkan bahwa pembelajaran khususnya olahraga kurang memperhatikan karakteristik siswa yang didasarkan pada perkembangan usia. Berdasarkan (Bompa, 1983), secara teori olahraga renang dapat dikenalkan kepada anak sejak usia dini 3-7 tahun, umur spesialisasi pada umur 10-12 tahun. Maka dari itu, cara memberikan pembelajaran olahraga di sekolah dasar jangan disamaratakan, siswa kelas III diberikan pembelajaran yang sama dengan siswa kelas VI. Karakteristik fisik, mental dan sosial dipastikan memiliki perbedaan, oleh karena itu semestinya diberikan model pendekatan pembelajaran yang berbeda. Usia anak Sekolah Dasar diperkirakan antara 7 - 12 tahun. Uraian diatas menimbulkan permasalahan apakah ada perbedaan hasil pembelajaran yang diberikan kepada anak yang memiliki perbedaan usia.

Pada aspek kognisi mempengaruhi penerimaan informasi; makin tinggi tingkat kognisi makin mudah menerima informasi. Bentuk aktifitas fisik disesuaikan dengan jenjang umurnya: periode umur 7-8 tahun (SD kelas 1 dan 2), periode umur 9 tahun (SD kelas 3), periode umur 10-11 tahun (kelas 4 dan 5), dan periode umur 12-13 tahun (kelas 6).

Olahraga yang teratur dapat bermanfaat untuk meningkatkan kesehatan (Sudrajat, 2004). Sebagai contoh, seseorang yang sudah terbiasa berolahraga secara teratur akan memiliki tingkat kebugaran yang lebih baik jika dibandingkan dengan orang yang tidak terbiasa berolahraga.

Kebugaran ada hubungannya dengan kesehatan karena kesehatan merupakan suatu keadaan sehat, baik secara fisik, mental, maupun sosial. Kebugaran ini memerlukan tingkat kebugaran yang cukup dari empat komponen kebugaran jasmani, yaitu kebugaran jantung, paru-paru, dan peredaran darah, lemah tubuh, kekuatan otot, serta kelenturan sendi.

Komponen kebugaran tersebut akan membantu mengurangi kemungkinan terjadinya penyakit degeneratif dan keadaan yang berkaitan dengan aktifitas fisik. Sebagai contoh adalah penyakit jantung koroner, kegemukan (obesitas) dan kelemahan sendi dan otot.

Menurut pendapat (Nurhasan, 2005) unsur-unsur kebugaran jasmani yang berhubungan dengan ketrampilan antara lain meliputi:

1) Kecepatan (speed) adalah kemampuan melakukan gerakan dalam waktu yang sesingkat-singkatnya.

2) Daya ledak (power) adalah kemampuan otot atau sekelompok otot untuk melakukan secara mendadak (eksplosif). Power merupakan perpaduan antara kekuatan dan kecepatan.

3) Keseimbangan (balance) adalah kemampuan untuk mempertahankan sikap tubuh yang tepat saat diam atau pada saat bergerak.

4) Kelincahan (agility) adalah kemampuan bergerak secara cepat dan berubah arah atau posisi tubuh tertentu secara tepat.

5) Koordinasi (coordination) adalah kemampuan untuk menggunakan panca indera seperti penglihatan dan pendengaran secara bersamasama dengan anggota tubuh tertentu dalam melakukan gerakan motorik secara harmonis dan tepat.

6) Kecepatan reaksi (reaction speed) adalah kemampuan untuk memberi reaksi setelah menerima ringkasangan secara cepat dan tepat.

Secara umum kebugaran ini membutuhkan suatu tingkat kebugaran yang berhubungan dengan kesehatan yang cukup tinggi. Komponen dasar kebugaran fisik meliputi Ketahanan otot, Tenaga otot, Ketangkasan, dan Kecepatan.

Sedangkan menurut pendapat yang dikemukakan oleh (Roji, 2004), secara umum komponen-komponen yang terdapat kebugaran jasmani antara lain meliputi :

a) Daya tahan jantung/peredaran darah, dan paru-paru

Copyright @ 2021 Jurnal JSTPM 2 (2) : 83-88 (Desember 2021) 
b) Kemampuan adaptasi biokimia

c) Bentuk tubuh

d) Kekuatan otot

e) Daya ledak otot

f) Daya tahan otot

g) Kelincahan

h) Kelenturan

i) Kecepatan reaksi

j) Koordinasi.

\section{METODE PELAKSANAAN}

Metode yang akan digunakan dalam Program Pengabdian Masyarakat adalah dengan praktek langsung dengan sistem offline tatap muka dan memberi instruksi dari instruktur untuk diikuti. Kami akan menghimbau para siswa-siswi di sekolah renang Akuatik Jakarta Timur untuk ikut dalam kegiatan sosialisasi pelatihan cabang olahraga renang. Hal pertama mungkin dengan pemberi tahuan bahwasannya akan melaksanakan kegiatan sosialisasi pelatihan cabang olahraga renang serta mempromosikan betapa pentingnya kesehatan dan kebugaran jasmani.

Target bagi penulis dalam kegiatan pengabdian masyarakat ini diharapkan, yakni :

a. Dapat dilaksanakannya kegiatan ini dengan metode praktek langsung dengan penjelasan teori sebelum pelaksanaanya.

b. Meningkatnya kualitas dan kuantitas para anak-anak tentang cabang olahraga renang kepada Peserta.

c. Meningkatnya sumberdaya manusia di bidang olahraga cabang renang.

d. Memberikan solusi terhadap berbagai permasalahan pergaulan anak-anak.

e. Siswa-siswi pemudi Jakarta Timur diharapkan menjadi penggerak dalam memasyarakatkan olahraga dan mengolahragakan masyarakat.

Luaran yang diharapkan dari kegiatan ini adalah:

a. Terciptanya kegiatan positif, siswa-siswi memiliki keahlian dan pengetahuan di dalam bidang cabang olahraga renang.

b. Adanya antusiasisme masyarakat untuk memperhatikan kesehatan dan kebugaran jasmani dan bukan hanya bagi siswa-siswi saja. Tapi siswa-siswi sebagai penggerak diseluruh mayarakat Jakarta Timur.

c. Meningkatkan keterampilan dan kebugaran jasmani bagi anak-anak melalui cabang olahraga renang.

d. Meningkatnya apresiasi orang tua untuk terus mengembangkan potensi anakanaknya khususnya di bidang olahraga renang.

e. Meningkatnya proses pengembangan minat dan bakat olahraga dari pembinaan olahraga untuk menghasilkan anak-anak yang sehat jasmani dan mempunyai jiwa yang sportif dan kompetitif.

f. Memberikan IImu pengetahuan teori dan praktek tentang cabang olahraga renang kepada Peserta.

Selain itu, kami juga akan mengundang guru-guru olahraga dan pelatih renang yang ada di Jakarta Timur untuk melanjutkan kegiatan sosialisasi penarapan kegiatan sosialisasi pelatihan cabang olahraga renang ini nantinya jika program pengabdian ini selesai. Untuk perijinannya, kami bekerjasama dengan sekolah renang Akuatik Jakarta Timur yang merupakan instansi menaungi kegiatan olahraga. Kegiatan pengabdian ini akan dilaksanakan dalam beberapa tahap, meliputi;

a. Tahap Persiapan

Tahap persiapan yang dilakukan untuk melaksanakan program ini meliputi;

1. Survei tempat pelaksanaan kegiatan.

2. Pembuatan proposal dan menyelesaikan administrasi perijinan pada instansi yang akan dilibatkan pada pelaksanaan kegiatan.

3. Pembuatan materi Renang slide show dan print out.

4. Mengadakan kerjasama dengan pelatih renang yang berpengalaman 
5. Persiapan peminjaman aplikasi media online yang digunakan untuk pemberian materi

6. Pembuatan dan penyebaran pamflet publikasi sosialisasi penarapan kegiatan sosialisasi pelatihan cabang olahraga renang.

b. Tahap Pelaksanaan Kegiatan

\section{HASIL DAN PEMBAHASAN}

\subsection{Hasil Pelaksanaan}

Kegiatan pengabdian masyarakat ini akan dilaksanakan selama 6 (enam) bulan terhitung sejak tahap persiapan hingga tahap akhir yaitu pelaporan hasil dari program ini. Adapun rencana kegiatannya adalah sebagai berikut :

Kami akan menghimbau para siswa-siswi di sekolah renang Akuatik Jakarta Timur untuk ikut dalam kegiatan sosialisasi pelatihan cabang olahraga renang. Hal pertama mungkin dengan pemberi tahuan bahwasannya akan melaksanakan kegiatan sosialisasi pelatihan cabang olahraga renang serta mempromosikan betapa pentingnya kesehatan dan kebugaran jasmani.

Selain itu, kami juga akan mengundang guru-guru olahraga dan pelatih renang yang ada di Jakarta Timur untuk melanjutkan kegiatan sosialisasi penarapan kegiatan sosialisasi pelatihan cabang olahraga renang ini nantinya jika program pengabdian ini selesai. Untuk perijinannya, kami bekerjasama dengan sekolah renang Akuatik Jakarta Timur yang merupakan instansi menaungi kegiatan olahraga.

Kegiatan dilaksanakan sebanyak 2 kali, mulai dari hari pertama di hari jumat dan hari kedua di hari sabtu diminggu pertama bulan februari. Untuk hari pertama, kami akan menyajikan instruktur berpengalaman untuk membawakan materi dasar-dasar cabang olahraga renang. Namun untuk kedua dan seterusnya, kami sendiri yang akan jadi instrukturnya.

\subsection{Pembahasan}

Setelah memberikan pengabdian melalui sosialisasi dan juga praktek kepada siswasiswi sekolah renang Akuatik Jakarta Timur untuk ikut dalam kegiatan. Para siswa-siswi merasakan hal positif seperti terjalinnya keakraban dan kebersamaan sesama dan terlihat antusias dalam berolahraga. Dampak positif dari 6 bulan pengabdian melalui sosialisasi, siswa-siswi menjadi tahu betapa pentingnya kesehatan dan kebugaran jasmani. Setiap pertemuan tim dari pengabdian memberikan pemahaman dan teori tentang kebugaran, kesehatan dan teori mengenai cabang olahraga renang itu sendiri, dan juga dapat memperbaiki dan meningkatkan teknik-teknik dalam cabang olahraga renang karena diadakan sesi praktek yang dilakukan oleh instruktur-instruktur berpengalaman.

\section{KESIMPULAN DAN REKOMENDASI}

Dengan adanya pelatihan pembinaan olahraga remaja ini dapat membangun pergaulan positif antar remaja dan tidak terjerumus dalam pergaulan negatif dengan cara memberikan aktifitas yang positif. Kemudian dapat menggali dan mengenali potensi dan bakat mereka sehingga mampu memanfaatkan waktu untuk mengembangkan potensi dan bakatnya tersebut. Agar nantinya semua potensi yang ada dapat diberdayakan dan dapat bermanfaat buat yang lainnya. Selain itu, sebagai upaya merangsang kembali kreatifitas pengembangan inovasi dan kreatifitas bagi remaja. Dan terakhir dapat meningaktnya kualitas dan kuantitas karya kreatifitas khususnya remaja.

Diharapkan untuk atlet, pelatih, serta pembina organisasi dan klub olahraga lebih memahami tentang pentingnya tahapan pengajaran dan proses latihan yang menarik dan berkelanjutan. Serta diharapkan dalam Sekolah renang, Akuatik Jakarta Timur, baik sebagai atlet ataupun pelatih dapat menerapkan dan mengembangkan pengetahuan yang diperoleh dalam pelatihan, untuk kegiatan olahraga prestasi, pendidikan maupun olahraga rekreasi. 


\section{DAFTAR PUSTAKA}

Badan Standard Nasional Pendidikan. (2006). Standard Isi Sekolah Menengah Atas dan Madrasah Aliyah. Jakarta: Departemen Pendidikan Nasional.

Bompa, T. O. (1983). Training Theory and Metodology. New Jersey: Human Kinetics, Ltd.

Ditjora Depdiknas. (2003). Penerapan IImiah dan Proses Sistematik dalam Pemanduan Bakat. Jakarta: Bagpro Fasilitasi Olahraga Prestasi.

Kantor Kemenegpora RI. (2005). Menkumham RI Patent No. 3 Undang-Undang Republik Indonesia tentang: Sistem Keolahragaan Nasional.

Kasiyono, D. (1979). Renang, Metoda, pola dan teknik.

Mutohir, T. (2004). Olahraga dan Pembangunan Meraih Kembali Kejayaan. Jakarta: Direktorat Jenderal Olahraga-Departemen Pendidikan Nasional.

Stork, S., \& Sanders, S. W. (2008). Physical Education in Early Childhood. The Elementary School Journal, 108(3), 197-206.

Sudrajat, N. (2004). Pendidikan Jasmani untuk SD. Bandung: PT. Sarana Panca Karya Nusa.

Nurhasan. (2005). Aktivitas Kebugaran. Jakarta: Depdiknas.

Roji. (2004). Pendidikan Jasmani. Jakarta: Erlangga. 